\title{
South Asia's evolving tobacco hydra: moving from quandary to hope
}

\author{
Prakash C Gupta (ㄷ , ${ }^{1}$ Namrata Puntambekar 다, ${ }^{1}$ Mary Assunta ${ }^{2}$
}

${ }^{1}$ Healis Sekhsaria Institute for Public Health, Navi Mumbai, Maharashtra, India ${ }^{2}$ Global Center for Good Governance in Tobacco Contro (GGTC) and Southeast Asia Tobacco Control Alliance (SEATCA), Bangkok, Thailand

\section{Correspondence to}

Dr Prakash C Gupta, Healis Sekhsaria Institute for Public Health, Navi Mumbai, Maharashtra 400701, India; pcgupta@healis.org

Received 29 August 2021 Accepted 26 November 2021

Check for updates

(C) Author(s) (or their employer(s)) 2022. No commercial re-use. See rights and permissions. Published by BMJ.

To cite: Gupta PC,

Puntambekar N, Assunta M. Tob Control

2022;31:142-145.

\section{ABSTRACT}

The South Asian region occupies a unique place in global tobacco control because of a broad spectrum of widely used tobacco products and the consequent mix of local and transnational tobacco industries. Cigarette use is especially high among males in many countries, while bidis are widely used in India, Bangladesh and Sri Lanka, and are very inexpensive. Smokeless tobacco use is a global problem, but the bulk of use is in South Asia and there is emerging promotion of newly developed tobacco and nicotine products across the region. With the transnational cigarette industry contributing a significant amount in taxes, the bidi industry employing millions of workers and many farmers engaged in tobacco farming, the industry is powerful and exploits this when countering proposed advancements in tobacco control policy. Despite industry interference and major challenges, this region has achieved remarkable successes in tobacco control, including large pictorial warnings that cover up to $80 \%-90 \%$ of the pack in some countries, stringent rules on depiction of tobacco in movies, bans on advertising and promotion, and smokefree public places. Key challenges include increasing the tax component of retail prices and reducing tax concessions, regulating newly developed products and countering the aggressive tactics of the tobacco industry. Strategies to advance tobacco control in the region may also include standardised packaging of tobacco products, sustained mass media campaigns to warn the population of the harms of tobacco use and promote use of available cost-covered cessation services, and supplyside measures such as vendor licensing.

\section{INTRODUCTION}

The tobacco epidemic in South Asia (Bangladesh, Bhutan, India, the Maldives, Nepal, Pakistan, Myanmar and Sri Lanka) is as diverse as its people. With a collective population of about 1.8 billion people, the region is known for a smokeless tobacco problem, controlled by local smokeless tobacco industries, while the smoking problem is focused on bidis, 'the poor man's smoke', as well as white cigarettes. In this mix, transnational tobacco companies have grown their white cigarette market through aggressive marketing, ${ }^{1-3}$ lobbying of governments, ${ }^{45}$ and acquisition and partnerships in local companies. ${ }^{6}$ However, South Asian countries have introduced some stringent tobacco control policies to protect public health through the implementation of the Framework Convention on Tobacco Control (FCTC), the only international treaty advanced by WHO. This paper looks at the challenges of the complex smoked and smokeless tobacco problem, the progress of tobacco control and what lies ahead for the region.

\section{SMOKED TOBACCO: BIDIS VERSUS CIGARETTES}

Bidis, conical-shaped bundles of coarsely grounded tobacco $(\sim 0.20 \mathrm{~g})$, are smoked mostly by $\mathrm{men}^{7}$ in India, Bangladesh and Sri Lanka. These hand-rolled sticks, costing less than a fifth of the cost of cigarettes, are popular among the poor. ${ }^{8}$ Taxes on bidis are so low $^{8}$ that small manufacturers can exploit small companies to avoid the taxes completely. The health risks from bidi smoking are equal to as those from the cigarette, as shown in a large Mumbai cohort study where the age-adjusted relative risk of all-cause mortality among male bidi smokers was 1.64 (95\% CI 1.47 to 1.81 ) and among cigarette smokers, 1.37 (95\% CI 1.23 to 1.53). Smoking even a small number of bidis conferred a substantial risk-the age-adjusted relative risk for smokers of one to five bidi per day was 1.42 (95\% CI 1.20 to $1.68)$, increasing for smokers of $>15$ bidis per day to 1.78 (95\% CI 1.57 to 2.02$){ }^{9}$

The manufacture of bidis is a small-scale cottage and home-based activity employing a large number of women and children, working without any protection and exposed to tobacco dust. ${ }^{10}{ }^{11}$ In India, while official data peg the number at about 4 million, ${ }^{12}$ the industry claims to employ 10 million workers ${ }^{13}$ and misuses exaggerated figures and the vulnerability of the poor to oppose tobacco control policies. The farmers group, Federation of All India Farmer Association, for example, claimed tax increases will affect the livelihood of millions of tobacco growers and farm workers. ${ }^{14}$

Alongside the bidi problem, the cigarette industry, especially transnational tobacco companies, are growing their sales and expanding their business in the region. ${ }^{15} 16$ In several countries, British American Tobacco (BAT), through its local subsidiary, has a dominant cigarette market position in Sri Lanka (84\%), India (76\%), Pakistan (67\%), Myanmar (BAT+JTI, ${ }^{17}$ 39.5\%) and Bangladesh $(63 \%) .{ }^{18}$ Although cigarette companies are private, government agencies often have shares in them. ${ }^{19}$ For example, in the largest tobacco company in India, ITC, two government-owned companies, Life Insurance Corporation of India and Specified Undertaking of the Unit Trust of India, hold 23.3\% shares.

Cigarettes are the most prevalent tobacco product in Sri Lanka, the Maldives and Pakistan, and the prevalence of cigarette smoking is especially high among men in Sri Lanka, Myanmar, the Maldives, Bangladesh and Nepal (table 1). While overall cigarette smoking prevalence in many of these South Asian countries is comparable with 
Table 1 Country-level tobacco use prevalence by type of tobacco by gender

\begin{tabular}{|c|c|c|c|c|c|c|c|c|c|}
\hline & \multicolumn{3}{|c|}{ Bidi } & \multicolumn{3}{|c|}{ Cigarettes } & \multicolumn{3}{|c|}{ Smokeless (SLT) } \\
\hline & Overall (\%) & Men (\%) & Women (\%) & Overall (\%) & Men (\%) & Women $(\%)$ & Overall (\%) & Men (\%) & Women (\%) \\
\hline Bangladesh $^{44}$ & 5.0 & 9.7 & 0.5 & 14.0 & 28.7 & 0.2 & 20.6 & 16.2 & 24.8 \\
\hline Bhutan $^{31} 45$ & - & - & - & 7.4 & 10.8 & 3.1 & 19.7 & 26.5 & 11.0 \\
\hline India ${ }^{20}$ & 7.7 & 14.0 & 1.2 & 4.0 & 7.3 & 0.6 & 21.4 & 29.6 & 12.8 \\
\hline Maldives ${ }^{46}$ & - & - & - & 18.8 & 34.7 & 3.4 & 2.6 & 3.9 & 1.4 \\
\hline Nepal & - & - & - & $16.4^{*}$ & $27.4^{47}$ & $5.5^{47}$ & $21.9^{*}$ & $40.1^{47}$ & $3.8^{47}$ \\
\hline Pakistan ${ }^{48}$ & - & - & - & 10.5 & 19.4 & 1.0 & 7.7 & 11.4 & 3.7 \\
\hline Sri Lanka & $4.4^{*}$ & $7.8^{49}$ & $<1.0$ & $40.6^{*}$ & $81.1^{49}$ & $<0.1$ & $15.8^{50}$ & $26.0^{50}$ & $5.3^{50}$ \\
\hline Myanmar ${ }^{51}$ & & & & $26.1 \dagger$ & $43.8 \dagger$ & $8.4 \dagger$ & 43.2 & 62.2 & 24.1 \\
\hline
\end{tabular}

*Estimated by authors.

tOverall for smoking tobacco.

other global regions (table 1), because of large populations, the number of cigarette smokers is significant (eg, 37.5 million cigarette smokers in India, ${ }^{20} 13.5$ million in Bangladesh ${ }^{21}$ ), with over 80 billion cigarettes produced in India alone. Cigarettes contribute a significant amount of government revenue from taxation and the industry exploits this when trying to counter tobacco control policies.

\section{SMOKELESS TOBACCO}

The latest global study indicates the prevalence of smokeless tobacco has remained fairly stable over time and is high in many regions. ${ }^{22}$ Smokeless tobacco use is globally recognised as an important component of the overall tobacco problem, ${ }^{23}$ estimated to cause over 652494 deaths each year. ${ }^{24}$ Although smokeless tobacco use has been reported from at least 121 countries, ${ }^{23}$ the bulk of the burden is in South Asia and is the most prevalent tobacco product in Myanmar, Nepal, India, Bangladesh and Bhutan. India alone bears over two-thirds of the global burden with 237 million users. Unlike smoking, smokeless tobacco use is common even among women in this region, especially in Bangladesh, Myanmar, India and Bhutan (table 1). This is of special concern, as just like smoking, smokeless tobacco use in pregnancy causes similar adverse reproductive outcomes. ${ }^{20} 25$

The ways of using smokeless tobacco products vary widely. They can be chewed (figure 1) (eg, gutka, betel quid, mawa), sucked (eg, khaini, zarda), or applied (figure 2) on teeth and gums (eg, mishri, tapkeer, tobacco tooth powder, gul, gudakhu, tobacco toothpaste), and even gargled (tuibur) and inhaled (snuff). The ways of making these smokeless tobacco products also vary from industrial manufacture to custom-made on-demand and self-made by the user, with many products

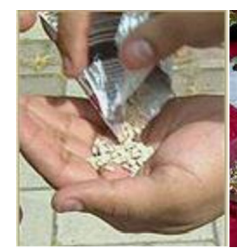

Gutkha

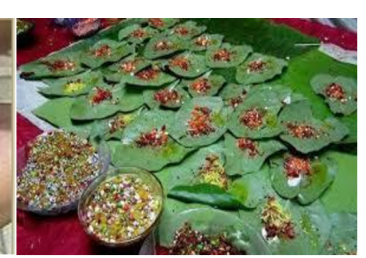

Betel quid

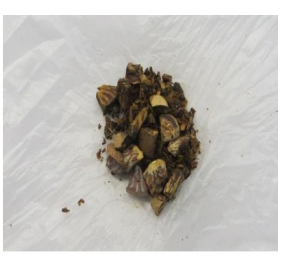

Mawa
Figure 1 Chewing tobacco. Gutka ${ }^{52}$ : A sweetened scented commercial mixture of supari, tobacco, catechu, lime, flavorings(typically menthol, saffron) and spices (typically cardamom, clove or eugenol, which is oil ofcloves). Betel quid ${ }^{33}$ : areca nut, betel leaf, lime and catechu. Other ingredients are for flavour, like spices and condiments. Any form of smokeless tobacco is incorporated in paan. Mawa ${ }^{33}$ : A scented and flavored mixture of shredded areca nuts, lime and tobacco. packaged and sold for single use. This makes them inexpensive and creates complications for tobacco control regulation in terms of combating affordability, environmental impact and tax administration.

\section{TOBACCO CONTROL POLICY SUCCESSES}

Until recently, Bhutan was the only country in the world to ban tobacco; however, it now allows the restricted sale of tobacco products to address smuggling which had worsened during the COVID-19 pandemic. $^{26}$ All countries in the region ban direct tobacco advertising; however, indirect and surrogate advertising remains a problem, often accomplished by giving a non-tobacco product the same brand name as a tobacco product. With a large movie industry in India, feature films exert a huge influence on the population and in the past have promoted tobacco unabashedly. ${ }^{27}$ India has imposed a ban on tobacco imagery in movies, and when smoking or tobacco use is depicted, a mandatory warning that scrolls is shown at the bottom of the screen. In addition, screening of an anti-tobacco advertisement before the film and during the interval is required. ${ }^{28}$

Media campaigns have been found to be effective in motivating quit attempts and have a longer-term impact on tobacco use behavior. ${ }^{2930}$ Pictorial warning labels (PWLs) are required on all tobacco products, including on conical packages of bidi bundles and on small, soft packages of smokeless tobacco products in all countries in the region, except Nepal. India, the Maldives,
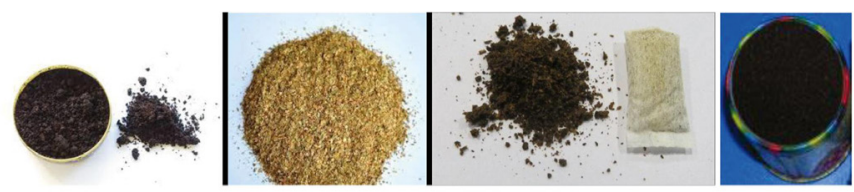

Mishri

Zarda

Snus

Gul

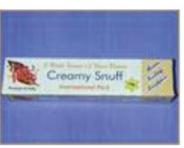

Toothpaste

Figure 2 Applying tobacco. Mishri ${ }^{33}$ : Masheri (misheri or mishri) - This is pyrolised and powdered tobacco. Users typicallyapply it to teeth and gums several times a day commonly in Maharashtra. Zarda ${ }^{33}$ : a scented chewing tobacco product containing spices including saffron and musk. It is being heavily promoted bann on gutka. Snuff ${ }^{52}$ : Powdered tobacco. $\mathrm{Gul}^{33}$ : A pyrolised tobacco product. Toothpaste- Marketed as creamy Snuff in toothpaste like tubes circumventing the law banning tobacco as an ingredient in any dentifrice. 
Nepal and Sri Lanka require some of the largest pictorial warnings globally (80\%-90\%). Smoke-free public places are mandatory in all countries in the region, although there is varying definition of public places across countries. ${ }^{31}$ The recent WHO Report on the Global Epidemic suggests Bangladesh, Bhutan and Pakistan have best practice smoke-free policies. ${ }^{31}$ Sri Lanka and Thailand have increased the age of legal sale of tobacco products to 21 years. ${ }^{32} \mathrm{~A}$ supply-side problem is high density of tobacco vendors reported from India ${ }^{33}$ perhaps in the other parts of the region also. Because of easy availability, accessibility and promotion of smokeless tobacco in a low-income area of Mumbai ${ }^{34}$ and the proximity near schools, ${ }^{35}$ some jurisdictions in India have initiated tobacco vendor licensing. ${ }^{36}$

\section{TOBACCO CONTROL POLICY CHALLENGES}

Over the next 10 years, countries in the region could prioritise the introduction of plain packaging of cigarettes and other tobacco products, and ban indirect and surrogate advertising to further protect the population in this region from tobacco product promotion. Governments could also be encouraged to invest in ongoing strong mass media campaigns to continually warn the population of the harms of tobacco use and to promote use of the cost-covered cessations services available in the region. ${ }^{31}$ Countries in the region have also yet to achieve the WHO recommended level of $75 \%$ or higher tax component in the retail price of tobacco products. A strong challenge for the next 10 years would be to reduce the tax concessions and increase the effective tax on bidis and smokeless tobacco products.

Another challenge for many of the countries in the region for the next few years is how to regulate electronic nicotine delivery systems (ENDS) and heated tobacco products (HTPs) and their promotion by transnational tobacco companies. For two countries in the region, the challenge will be trying to maintain the current strong regulation, with Sri Lanka one of the first countries in the world to ban the sales of ENDS in $2016^{31}$ and India imposing a complete ban on ENDS and HTPs in December 2019 through an act of parliament, although industry lobbying and efforts are still vigorously trying to overturn it. ${ }^{37}$

Another key challenge over the next decade includes effectively dealing with the transnational tobacco companies' influence over tobacco control policy progress, for cigarettes and also bidis and smokeless tobacco. The smokeless tobacco market in South Asian countries is very large and therefore lucrative for transnational companies, with the Swedish Match Company previously trying to penetrate the Indian market ${ }^{38}$ unsuccessfully. Transnational tobacco companies have routinely applied a tried and tested tactic of incremental pressure in the region over the past decade. This involves promotion of 'sensible regulation' at one end of the spectrum through to a thinly veiled threat of 'withdrawing investment' or legal action when all else fails. For example, the Sri Lankan government was sued by BAT when it introduced $80 \%$ coverage PWLs. ${ }^{39}$ The Indian government faced multiple lawsuits challenging its policies on smoking imagery in movies, point-of-sale advertisements and PWLs. When India hosted the WHO-FCTC Conference of Parties in November 2016, the industry organised a farmers' protest to put pressure on the government to allow them to participate in the meeting. ${ }^{40}$ BAT even managed to persuade the British High Commissioners in Bangladesh and Pakistan to lobby on its behalf to avoid paying tax owed to the government ${ }^{41}$ and to drop the government's plan for larger pictorial warnings on cigarette packs, ${ }^{42}$ respectively, despite the British government having guidance for their diplomatic mission to not promote tobacco. In an exercise measuring the interference of the tobacco industry, India scored 61, Pakistan 41, Nepal 43, Sri Lanka 44, Maldives 48, Myanmar 54 and Bangladesh $68(0=$ least interference; $100=$ greatest interference), demonstrating that there is a lot of room for improvement in the region. ${ }^{43}$

\section{CONCLUSION}

The South Asian region is characterised by a diverse set of widely used tobacco products including bidis, different types of smokeless tobacco products, as well as cigarettes. Consequently, there is a mix of local and transnational tobacco industries that employ millions of workers, and many farmers in the region are engaged in tobacco farming. Despite industry interference, the region has made huge progress in tobacco control over the past decade, including large PWLs, tobacco advertising bans and strong regulation around the depiction of tobacco in movies, and has addressed several difficult issues such as introducing PWLs on conical paper-wrapped bidi bundles and on small, soft packages of smokeless tobacco products. It has also demonstrated resilience in the face of tobacco industry challenges, often succeeding against the transnational tobacco industry. Continuing industry interference remains a major challenge.

\section{What this paper adds}

- The specific issues the South Asian region faces in advancing tobacco control are different from the rest of the world. It outlines the numerous successes that this region has had despite industry interference.

Acknowledgements The authors extend special thanks to Tobacco Control editors for their comments and editorial guidance.

Contributors PCG conceptualised the manuscript and wrote the paper. MA and NP helped in manuscript editing, manuscript review, and provided critical comments and helped in finalisation of the paper.

Funding The authors have not declared a specific grant for this research from any funding agency in the public, commercial or not-for-profit sectors.

Competing interests None declared.

Patient consent for publication Not applicable.

Ethics approval This study does not involve human participants.

Provenance and peer review Commissioned; externally peer reviewed.

\section{ORCID iDs}

Prakash C Gupta http://orcid.org/0000-0002-1265-0372

Namrata Puntambekar http://orcid.org/0000-0002-4797-7463

\section{REFERENCES}

1 Handley L. Children around the world are being exposed to cigarette advertising near their schools. CNBC, 2018. Available: https://www.cnbc.com/2018/03/09/cigaretteschildren-are-being-exposed-to-tobacco-advertising.html

2 Arora M, Nazar GP. Prohibiting tobacco advertising, promotions \& sponsorships: tobacco control best buy. Indian J Med Res 2013;137:867-70.

3 Siraj M. Pakistan extends its ban of tobacco advertising. WHO Framework Convention on Tobacco Control Secretariat. Available: https://untobaccocontrol.org/impldb/ pakistan-extends-its-ban-of-tobacco-advertising/

4 Noki I. Letter from Ambassador of Japan of Bangladesh addressed to finance Minister of Bangladesh, 2021. Available: https://content.tobaccotactics.org/uploads/2021/03/ Ambassador-of-Japans-Letter-for-JTI_.pdf

5 Express Tribune. UK high commissioner accused of lobbying for cigarette companies in Pakistan, 2015. Available: https://tribune.com.pk/story/872903/uk-high-commissioneraccused-of-lobbying-for-cigarette-companies-in-pakistan

6 Staff Correspondent. Single biggest Fdl in Bangladesh. The daily StAR, 2018. Available: https://bit.ly/3luFIAb 
7 Gupta PC, Asma S, eds. Bidi smoking and public health. New Delhi: Ministry of Health and Family Welfare, Government of India, 2008. https://www.who.int/tobacco/ publications/prod_regulation/bidi_smoking_public_health.pdf

8 Jha P, Guindon E, Joseph RA. A rational taxation system of Bidis and cigarettes to reduce smoking deaths in India. Econ Polit Wkly 2011;46:44-51.

9 Gupta PC, Pednekar MS, Parkin DM, et al. Tobacco associated mortality in Mumbai (Bombay) India. Results of the Bombay Cohort Study. Int J Epidemiol 2005:34:1395-402.

10 Sabale RV, Kowli SS, Chowdhary PH. Working condition and health hazards in beedi rollers residing in the urban slums of Mumbai. Indian J Occup Environ Med 2012;16:72.

11 Kim J, Rana S, Lee W, et al. How the bidi tobacco industry harms child-workers: results from a walk-through and quantitative survey. Saf Health Work 2020;11:143-51.

12 Arora M, Datta P, Barman A, et al. The Indian bidi industry: trends in employment and wage differentials. Front Public Health 2020;8:572638.

13 Narayan K. Deferment of pictorial warnings give beedi workers a breather, 2008. Available: https://bit.ly/3jADFaW

14 PTI. Tobacco farmers' body urges govt for pragmatic approach on cigarette taxation. Bloombergquint, 2020. Available: https://www.bloombergquint.com/business/ tobacco-farmers-body-urges-govt-for-pragmatic-approach-on-cigarette-taxation

15 Tobacco Reporter. BAT invests in Bangladesh. 2021 Jul 30. Tobacco Reporter Available: https://tobaccoreporter.com/2021/07/30/bat-invests-in-bangladesh/

16 Tobacco Asia. Foreign investment in India's tobacco industry proposed. Tobacco Asia, 2020. Available: https://www.tobaccoasia.com/news/foreign-investment-in-indiatobacco-industry-proposed/

17 Southeast Asia Tobacco Control Alliance. SEATCA tobacco industry monitor. Myanmar: SEATCA; 2019. Available: https://timonitor.seatca.org/myanmar/ [Accessed 02 Nov 2021].

18 Euromonitor report 2019. Available: https://www.euromonitor.com/consumers-in2019/report [Accessed 20 Oct 2021].

19 South East Asian region: Tobacco Tactics, University of Bath. Available: https:// tobaccotactics.org/wiki/south-east-asian-region/ [Accessed 2 Nov 2021].

20 Global adult tobacco survey. India: 2016-2017. Available: https://bit.ly/3xsckNb

21 Ministry of Health and Family Welfare. Global adult tobacco survey - Bangladesh report, 2009. Available: https://bit.ly/3AkmGAx

22 Hatsukami DK, Zeller M, Gupta PC. Smokeless tobacco and public health - a global perspective, 2014. Available: http://cancercontrol.cancer.gov/brp/tcrb/globalperspective/index.html

23 Sinha D, Agarwal N, Gupta P. Prevalence of smokeless tobacco use and number of users in 121 countries. Br J Med Med Res;9:1-20.

24 Sinha DN, Suliankatchi RA, Gupta PC, et al. Global burden of all-cause and causespecific mortality due to smokeless tobacco use: systematic review and meta-analysis. Tob Control 2018;27:35-42.

25 World Health Organization. Country Office for Bangladesh. Global adult tobacco survey: Bangladesh report 2009. Ministry of Health and Family Welfare, 2009.

26 The Straits Times. Bhutan lifts tobacco ban to temper demand for smuggled cigarettes during COVID-19 pandemic, 2020. Available: https://www.straitstimes.com/asia/ south-asia/bhutan-lifts-tobacco-ban-to-temper-demand-for-smuggled-cigarettesduring-covid-19

27 Arora M, Mathur N, Gupta VK, et al. Tobacco use in Bollywood movies, tobacco promotional activities and their association with tobacco use among Indian adolescents. Tob Control 2012;21:482-7.

28 Nazar GP, Arora M, Sharma N, et al. Changes in tobacco depictions after implementation of tobacco-free film and TV rules in Bollywood films in India: a trend analysis. Tob Control. In Press 2021. doi:10.1136/tobaccocontrol-2021-056629. [Epub ahead of print: 26 Jul 2021].

29 Murukutla N, Turk T, Prasad CVS, et al. Results of a national mass media campaign in India to warn against the dangers of smokeless tobacco consumption. Tob Control 2012:21:12-17.

30 Murukutla N, Bayly M, Mullin S, et al. Male smoker and non-smoker responses to television advertisements on the harms of secondhand smoke in China, India and Russia. Health Educ Res 2015;30:24-34.
31 World Health Organization. WHO report on the global tobacco epidemic 2021: addressing new and emerging products, 2021. Available: https://www.who.int/ publications/i/item/9789240032095

32 The Sri Lankan economy charting a new course edited by Prema-chandra Athukorala, Edimon Ginting, HAL Hill, and Utsav Kumar. Available: https://www.adb.org/sites/ default/files/publication/373316/sri-lankan-economy.pdf

33 Reddy KS, Gupta PC. Report on tobacco control in India. Ministry of Health and Family Welfare, Government of India, New Delhi, 2004. (a) Historical records and anecdotes: from the middle ages to modern times. p 7-18; p 43-48. Available: http://www.who. int/fctc/reporting/Annex6_Report_on_Tobacco_Control_in_India_2004.pdf

34 Nair S, Schensul JJ, Bilgi S, et al. Local responses to the Maharashtra gutka and pan masala ban: a report from Mumbai. Indian J Cancer 2012;49:443-7.

35 Mistry R, Pednekar M, Pimple S, et al. Banning tobacco sales and advertisements near educational institutions may reduce students' tobacco use risk: evidence from Mumbai, India. Tob Control 2015:24:e100-7.

36 Chauhan G. Licensing tobacco vendors in the state of Himachal Pradesh in India challenges, opportunities and the way forward to implement the new legislation. Tob Induc Dis 2018;16:599.

37 Amalia B, Kapoor S, Sharma R, et al. Online sales compliance with the electronic cigarettes ban in India: a content analysis. Int J Public Health 2020;65:1497-505.

38 Gupta PC. India: Swedish match steps in. Tob Control 2001;10:304e-304

39 Campaign for Tobacco Free Kids. Ceylon Tobacco v Minister of Health. Available: http://www.tobaccocontrollaws.org/litigation/case_listing/141

40 Kalra A. Exclusive: India's tobacco industry, government face off ahead of WHO conference, 2016. Available: https://www.reuters.com/article/us-india-tobaccoidUSKCN12R0P9

41 Doward J. British diplomat lobbied on behalf of big tobacco. The Guardian, 2017. Available: https://bit.ly/3Al46IF

42 The Express Tribune. UK high commissioner accused of lobbying for cigarette companies in Pakistan, 2015. Available: https://bit.ly/3rZUArq

43 Reyes JL. SEATCA tobacco industry interference index: implementation of article 5.3 of the WHO framework convention on tobacco control in Asian countries. Bangkok, Thailand: Southeast Asia Tobacco Control Alliance (SEATCA), 2020.

44 Published by Bangladesh Bureau of Statistics and National Tobacco Control Cell. Global Adult tobacco Survey Bangladesh Report 2017. Available: https://ntcc.gov.bd/ ntcc/uploads/editor/files/GATS\%20Report\%20Final-2017_20\%20MB.PDF [Accessed 1 Sep 2021].

45 Bhutan tobacco factsheet 2018 R4. Available: https://apps. who.int/iris/bitstream/ handle/10665/272671/wntd_2018_bhutan_fs.pdf?sequence=1 [Accessed 21 Aug 2021]

46 FACTSHEET. Maldives: Maldives tobacco factsheet 2018 R4, 2018. Available: https:// apps.who.int/iris/bitstream/handle/10665/272674/wntd_2018_maldives_fs.pdf? sequence $=1$ \&isAllowed $=y$ [Accessed 20 Aug 2021]

47 Shrestha N, Mehata S, Pradhan PMS, et al. A nationally representative study on sociodemographic and geographic correlates, and trends in tobacco use in Nepal. Sci Rep 2019;9:2682.

48 Global adult tobacco survey Pakistan 2014, Pakistan Health Research Council. Available: https://www.who.int/tobacco/surveillance/survey/gats/pak-report.pdf [Accessed 23 Aug 2021]

49 Trend survey on tobacco: annual trend survey on tobacco smoking in Sri Lanka 2018. Available: http://adicsrilanka.org/wp-content/uploads/2019/10/TS-Tobacco-SmokingReport-2018.pdf [Accessed 25 Aug 2021].

50 Srilanka tobacco factsheet 2018, 2018. Available: https://apps.who.int/iris/bitstream/ handle/10665/272688/wntd_2018_srilanka_fs.pdf? sequence=1 [Accessed 25 Aug 2021].

51 Core Questionnaire of the reporting instrument of WHO FCTC, Myanmar, Ministry of Health and Sports, 2020. Available: https://untobaccocontrol.org/impldb/wp-content/ uploads/Myanmar_2020_WHOFCTCreport.pdf

52 Bhonsle RB, Murti PR, Gupta PC. Tobacco habits in India. In: Gupta PC, Hamner JE, Murti PR, eds. Control of tobacco-related cancers and other diseases. Proceedings of an international Symposium, TIFR, Bombay, January 15-19, 1990. Bombay: Oxford University Press, 1992: 25-46. 